\title{
Oil, Risk Analysis Techniques, Maritime Security and Safe Passage in Pirate Infested Gulf of Guinea Waters
}

\author{
Nana Raymond Lawrence Ofosu-Boateng \\ College of Transport and Communications, Shanghai Maritime University, Shanghai, China \\ Email:boatnana@gmail.com
}

How to cite this paper: Ofosu-Boateng, N.R.L. (2017) Oil, Risk Analysis Techniques, Maritime Security and Safe Passage in Pirate Infested Gulf of Guinea Waters. Open Journal of Social Sciences, 5, 98-109. https://doi.org/10.4236/jss.2017.512008

Received: October 24, 2017

Accepted: December 11, 2017

Published: December 14, 2017

Copyright $\odot 2017$ by author and Scientific Research Publishing Inc. This work is licensed under the Creative Commons Attribution International License (CC BY 4.0).

http://creativecommons.org/licenses/by/4.0/

\section{(c) (i) Open Access}

\begin{abstract}
Globalization has been the necessary catalyst that has catapulted international trade to new heights but not without some associated challenges. In practice globalization has in some cases created a backlash due to inequalities among regions. Seaborne trade accounts for close to $90 \%$ of world trade. Unfortunately, some of the sea lanes and routes have become vulnerable to pirate attacks, armed robbery, gun-running, illegal, unreported, and unregulated fishing, drug trafficking, human trafficking and marine pollution. Securing safe passages to ensure smooth supply chain operations embraces the involvement of many actors and stakeholders. Technology is being harnessed to mitigate the scourge of the piracy menace. With the help of the Vessel Traffic Service along some of the littoral countries in the Gulf of Guinea, constant monitoring is achieved thus ensuring a partial safe corridor for ocean going vessels to ply. This paper examines the interplay of the threat of piracy to the safety of navigation, maritime security, seafarers and the risk analysis methods involved in ensuring that sea lanes which form a pivotal vital link to the energy needs of the Gulf of Guinea are met.
\end{abstract}

\section{Keywords}

Gulf of Guinea, Maritime Security, Risk Analysis Techniques, Vessel Traffic Service

\section{Introduction}

The dynamics of International trade has changed such that it is impossible for one country to be self sufficient in all its needs. At different levels all countries acquire what they lack domestically and export what they produce. This inter- 
dependence has fostered greater connectivity between people and countries that were previously not connected. The derived benefits are enormous as there is prosperity and transfer of technology that both countries can seize the advantage [1].

The shipping industry is seen as a very sophisticated one with many facets and parties based in different locations around the world. It is known that about $90 \%$ of the world trade volume is transported by sea going vessels [2]. By globalization, as according to [3], shipping has found its place among industries as an international player. Presently, it is common place to find mix crew vessels with a multicultural setting and crew members drawn from different countries. Ships now have the option to sail traditional registry or open registry, whichever is found attractive. Markets have become more globalised and far reaching. This international nature of shipping allows room for the application of regulations which is affected by the states [4].

The Gulf of Guinea (GoG) has since 2011 been put in the international community spot light on piracy related issues. According to the international Maritime Bureau (IMB), in 2011 the incidents of attempted piracy attacks were 439 in the Gulf of Guinea. This account has within a decade tagged the Gulf of Guinea as one of the most dangerous maritime routes in the world. Maritime trade is hugely threatened and the economic ramifications are immense. Since the Gulf of Guinea provides a vital link between Europe, the Americas and Africa. In part, the cause of global interest in the Gulf of Guinea is due to the importance of Maritime Transportation, assisting in transportation and foreign trade. The early 1980's is when piracy started in the Gulf of Guinea. Available statistics of the International Maritime Bureau (IMB) in the year 2015 showed a fluctuation in the operations of piracy. The year 2003 recorded 64 attacks, though it decreased to 56 in 2004 and 25 in 2005. In 2006 it increases from 31 to 53 in 2007 and 59 in 2008. In 2011, 53 cases were reported which increased to 62 in 2012. The IMB reported ten hijackings, four killings, 26 kidnappings and 207 crew taken as hostages. Nigerian waters accounts for (54\%) pirate attacks. The other GoG nations from (2003-2012) which suffered such attacks are Guinea (7\%), Cote d'voire (5\%) and Benin (5\%). The GoG has become a very attractive piracy zone and has managed to surpass the Gulf of Aden in acts of piracy. This region is home to some oil producing countries churning out five billion barrels of oil daily.

The GoG has become a very active piracy zone and has managed to surpass the Gulf of Aden in acts of piracy. This region is home to some oil producing countries churning out five million barrels of oil day. Many ships traverse this ocean stretch and the most vulnerable targets are ship with oil cargoes [5]. The modus operandi of the GoG pirates is to attack and seize whatever cargoes the ship is carrying. These encounters in this area could get violent as the pirates are heavily armed with sophisticated weapons. The territorial waters of Benin and Nigeria have been marked as High Risk Area (HRA) by the International Bargaining Forum (IBF) [6]. Additionally, this area has been declared a High Risk 
Area by the Joint War Committee (JWC) which has resulted in insurance companies charging the ship owners high premiums.

The characteristic feature of piracy in the GoG is petro piracy. Oil tankers have been very vulnerable and an easy target for pirates operating in this area [7]. The United Nations Office on Drugs and Crime (UNODC) used the term "Petro-piracy" to describe this act as the interest was not focused on ransom for the ship crew but the oil cargo [8]. The pirates did not seek to harm the captured crew and treated them with less violence [9].

According to the International Maritime Bureau (IMB), the coast of Nigeria recorded a high incidence of 29 attacks in 2013. This reduced to 13 in 2014 and 12 in 2015 . However, it peaked to 31 attacks in 2016. The five locations as indicated in Figure 1, contributed to $65 \%$ of pirate attacks from January to September 2016.

\section{Issues of Manning}

To contain the threat of maritime piracy, personnel on a vessel should be highly trained in antipiracy maneuvers and contingencies. The International Ship and Port Facility (ISPS) Code by the International Maritime Organization (IMO) was concluded in December 2002 and entered into full force on July $1^{\text {st }} 2004$. This code became necessary after the 9/11 attacks in the United States of America with the perception that such similar or varied acts of terrorism could be replicated on ships or port facilities. The code contained generic anti piracy measures to address any such threats. Additionally, to safe guard the competencies required onboard, the IMO has instituted the International Convention on Standards of Training, Certification and Watch keeping for seafarers (STCW) 1995 and as amended in 2010 (Manila Amendments). An amendment to the STCW 95 started in 2006 but culminated in the Manila Conference of June 2010. The full amendment came into force on January $1^{\text {st }} 2012$. The IMO model courses associated with the convention required that ship personnel deal with pirate related topics such as: 1) Ship Security Officer (model course 3.19). 2) Security Awareness Training for all Seafarers (model course 3.26) [7].

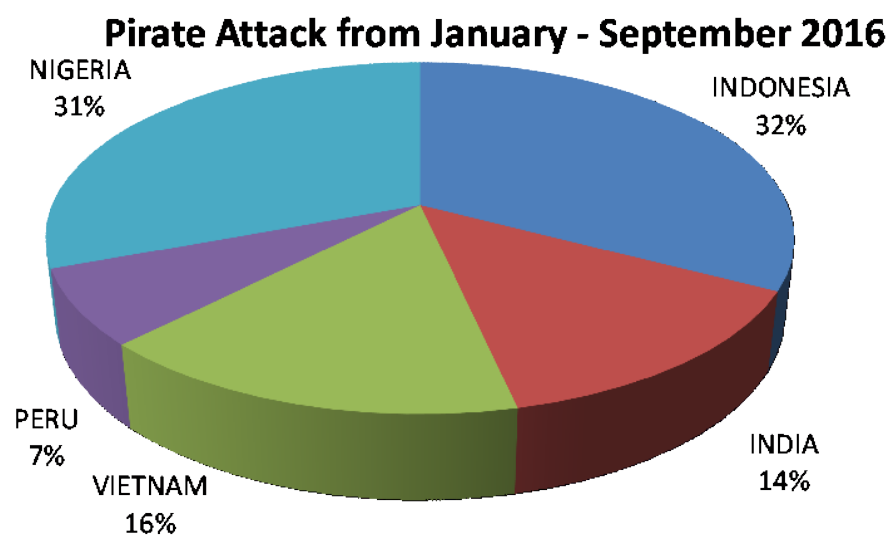

Figure 1. Pirate Attack from January to September 2016. Source: [10]. 
Given the peculiarities associated with shipping it is a daunting task selecting the right caliber of personnel to man a vessel. Most ship owners contract crewing or manning agents to undertake this exercise. Shipping companies seek to make profits while engaging competent and efficient crew for the vessel's operation. The nationalities of the crew may be at the owner's discretion but the vessel has to fulfill requirements of the flag state under which it is operating. The vessel is issued with a Safe Manning Certificate (SMC) denoting the number of required qualified crew to work on board. The SMC has to be complied with as this suggests the level at which a vessel can efficiently operate with the crew. Retaining a crew member after a satisfactory discharge of duties saves a shipping company from time loss and additional expenses. The retention rate or keeping competent seafarers on board is gradually calculated using the following formula:

$$
\% \text { Retention Rare }(R R)-100-\left[\frac{\{S-(V T+B T)\} * \times * 100}{A E}\right]
$$

where $R R=$ Retention Rate

$S=$ Total number of Terminations from various reasons

$U T=$ Unavoidable Terminations (retiring, long term sickness)

$B T=$ Beneficial Terminations (under performers)

$A E=$ Average number of employees working for a 12 month period as calculation is made.

\section{Risk}

The reliance of mankind on the cosmos and religion in their future affairs is giving way to scientific technologies and the ability to use proven decision making processes [11]. Risk has various interpretations and depends on where it is being used and the context it seems to portray. According to [12] risk could be used as a decision making factor and defined risk as "reflecting variation in the distribution of possible outcomes, their likelihood and their subjective values." According to [13] terrorism risk does not exist without the existence of threat, the presence of vulnerability and the potential consequences, thus the [14] gives the definition of risk as "the combination of the frequency and the severity of the consequence". It is also described simply in content as "the danger of loss, injury or other adverse consequence" [15]. In general, the ability to identify a hazard is essential in other to determine the risk level by way of combining the consequence and probability. Risk analysis can be classified into two main groups. It could be done by qualitative or quantitative methods. For the quantitative technique, values are measured in the analysis by engaging several resources in the evaluation. The initial step of the risk analysis is to define an existing problem and describe the system. The qualitative approach employs a discrete risk scales method to evaluate the land guard and its significance in relation to risks

\section{Risk Analysis}

According to [16] when assessing and evaluating the uncertainties associated 
with an event, risk is defined as the potential for loss as a result of a system failure, and can be influenced by a pair of factors, one being the probability of occurrence of an event, so called failure scenario, and the other being the potential outcome or consequence associated with the events occurrence. This can be represented as in the relationship below:

$$
\text { Risk }\left[\frac{\text { Consequence }}{\text { Time }}\right]=\text { Likelihood }\left[\frac{\text { Event }}{\text { Time }}\right] \times\left[\frac{\text { Consequence }}{\text { Time }}\right]
$$

Risk estimation and risk evaluation are jointly associated with risk analysis. The former comprises of finding the event probability and consequence assessment while the latter is about acceptability and evaluation.

\section{Quantitative Risk Assessment Models}

In simplistic terms, Quantitative Risk Assessment (QRA) employs a numerical estimate of the probabilite defined as: $y$ that a defined harm will occur due to a particular events occurrence. According to the [14] report on Formal Safety Assessment (FSA) the following terms are

Hazard: a potential to threaten human life, health, property or the environment.

Risk: combination of frequency and severity of consequence.

Frequency: number of occurrences per unit time (eg. per year)

Accident: an unintended event involving fatality, injury, ship loss or damage to property loss or damage, or environmental damage.

Consequence: Outcome of an accident

Collision: Striking or being struck by another ship, regardless of whether underway, moored or anchored. This category does not include under the waterline.

For collision [17] came up with a Bayesian net work relevant to the officer of the during a collision course encounter. According to [18] the summation of all possible situations goes into finding the probability of a collision. Collision:

$$
\begin{aligned}
P(\text { Collision })= & \sum_{i=1}^{k} \sum_{i=1}^{l} P\left(\text { Collision } \mid \text { Incident }_{i} \text { Situation }_{j}\right) . \\
& \times P\left(\text { Incident }_{i} \text { Situation }_{j}\right) \times P\left(\text { Situation }_{j}\right)
\end{aligned} .
$$

1) $P\left(\right.$ Situation $\left._{j}\right)=$ Probability that a particular combination of val ues for the factors in the system

2) $P\left(\right.$ Incident $_{i} \mid$ Situation $\left._{j}\right)=$ Probability that a particular triggering incident in a situation occurs

3) $P\left(\right.$ Collision $\mid$ Incident $_{i}$ Situation $\left._{j}\right)=$ Probability that collision occurs once a situation triggering an incident occurs.

$$
P\left(\text { Incident }_{i} \text { Situation }_{j}\right) \times P\left(\text { Collision } \mid \text { Incident }_{i} \text { Situation }_{j}\right)=P(\text { Collision })
$$

We can use elicitation method, Bayesian estimation, and Bayesian respectively for (3), (2) and (1).

Macduff using Geometric Probability Estimation [19] came up with a model 
well suited for estimating the probabilities of grounding and collisions.

$$
\text { Grounding }\left(P_{g}\right)=\frac{4 T}{\pi C}
$$

$T=$ Stopping Distance

$C=$ The width of the Channel

For ship collision Macduff proposed an approximation of the geometric probability.

$$
\text { Collision }\left(P_{c}\right)=\frac{X \cdot L}{D^{2}} \frac{\sin (\theta / 2)}{g 25}
$$

$D=$ The average distance between vessels (nautical miles)

$L=$ The average vessel length (meters)

$X=$ Actual length of vessel's track (nautical miles)

Assumption was made for the velocity of the vessel and its angle of approach as respectively $v$ and $\theta$.

\section{Limitations of Risk Analysis}

Risk analysis comes in very handy when making a comprehensive assessment of a system taking into account its associated hazards [20]. Fully obtaining information and understanding a system forms the bedrock on which other risk control measures could be implemented. The limitations which associate risk analysis in the domain of quantitative analysis has to do with scarcity of reliable statistical data. By using a mathematical methodology, the Monte Carlo Simulation (MCS) helps through quantitative risk analysis to come out with the probabilities that an unwanted event is likely to occur. The MCS generates individual probability distribution for every input and values are randomly selected from the appropriate distribution. Multiple Simulations running into their hundreds are made and the result depicts the distributions outcome. The Simulation does not determine a single point value with regards to variables. The MCS works efficiently in analyzing what each input has on the end result [21] [22]. There is an element of subjectivity in risk analysis as approximations are often made to assist in the decision making process. There is difficulty in the analysis of risk though the input data could be quite extensive and comprehensive. In a bid to analyze the aftermath often leads to varied analytical results. Determination of the exposure factor is a very daunting task to achieve and could come with many approximations. In the event of assessments, scanty or uncertain outcomes often compromise statistical data and produces very unreliable results. The interaction of man and machine often creates the setting for human errors to occur. According to [20] this is evident in major collisions at sea that have happened. Maritime accident investigations have shown that about $75 \%$ to $95 \%$ of the accidents do happen due to human error [23] [24].

\section{Formal Safety Assessment}

Human error and bad seamanship culminated in the terrible tragedy of the Herald 
of Free Enterprise on the $6^{\text {th }}$ of March 2017. The Passenger RoRo vessel had left the harbour with the bow door open. As a RoRo vessel, this neglect compromised the stability of the vessel as water started flooding the vessel. The vessel capsized resulting in the death 150 passengers and 38 crew members [25]. Lord Carver led the investigation team which formed the catalyst into the introduction of the Internal Safety Management (ISM) Code and the Ship Formal Safety Assessment (FSA) [26] [27]. A novel approach to marine safety is FSA which makes use of technologies of risk and cost-benefit assessment to aid in the decision making process.

The FSA methodology has to be approached in a holistic manner to do risk assessment. This usually falls into five clear steps as depicted in Figure 2. The primary objective unlike the current method or approach is to identify what might not go right called the Hazard Identification as depicted in step one. Afterwards one needs to establish the probability or likelihood of occurrence. This puts us in step two or the Risk Analysis stage. Improving the situation after the Risk Analysis has been done would place us in step three which is Risk Control Options identification. Determining how much or if the system has become much better, involves Cost Benefit Assessment (CBA) or step four. Step five involves taking a decision to salvage the system. While the FSA is a useful tool, it is normally used in a generic setting, where a set of rules and regulations are considered in the process.

\section{Maritime Security}

Maritime Security can be defined as "those measures employed by owners, operators, and administrators of vessels, port facilities, offshore installations and other marine organizations or establishments to protect against seizure, sabotage, piracy, pilferage, annoyance, or surprise" [28]. African Command (AFRICOM) is the United States (US) combatant command responsible for the

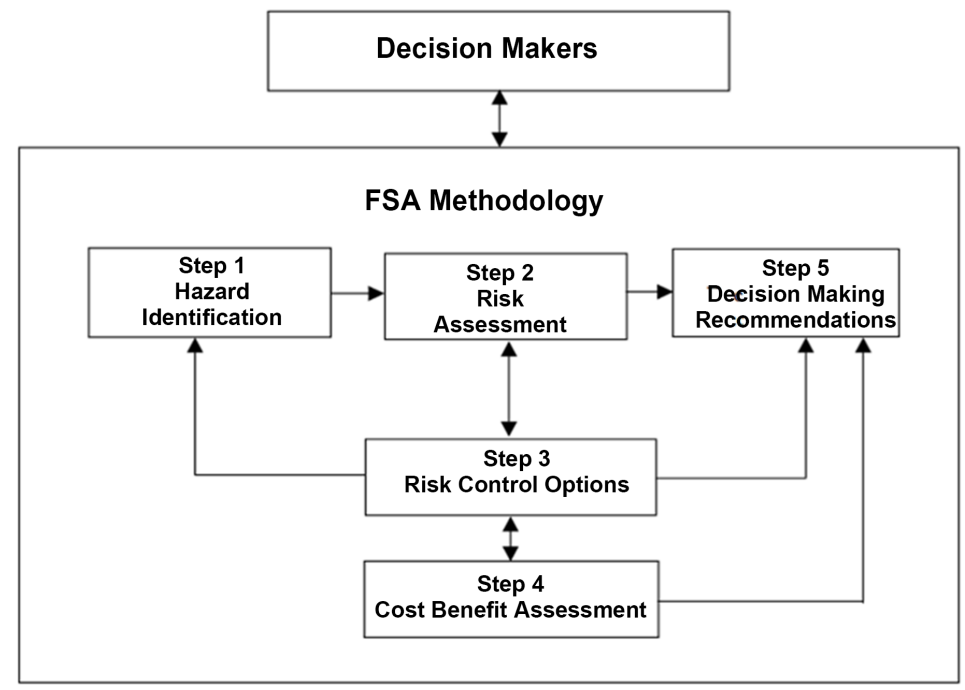

Figure 2. Flow chart of the FSA methodology. Source: [20]. 
continent of Africa. In the GoG the US does not conduct counter piracy assets in an arrangement called the African Partnership Station (APS) which became operational in 2007. APS primarily is a United States Forces Africa (NAVAF) tool bothering on maritime security with the emphasis on forging cooperation with Africa in Maritime Security Awareness, infrastructure and capacity to respond. A practical demonstration of this US Gulf of Guinea cooperation is the 'Obangame Express' exercise held in 2013. The countries that participated in this exercise are: Belgium, Benin, Brazil, Cameroon, Cameroon, Cote d'Ivoire, Equatorial Guinea, France, Gabon, the Netherlands, Nigeria, the Republic of Congo, Sáo Tome and Principe, Spain and the United States [29].

\section{Illegal, Unreported and Unregulated [IUU]}

The term "Pirate fishing" is being used to represent Illegal, Unreported and Unregulated (IUU) fishing. From a global perspective, estimates of between $\$ 10$ to $\$ 23$. billion is lost annually [30]. The close proximity to the sea allows the littoral states of the Gulf of Guinea obtain a livelihoods through fishing. This fish provides a daily sustenance and form of human security. As a means, to combat this challenge the Food and Agriculture (FAO) adopted the International Plan Of Action (IPOA-IUU) in 2001. This plan provided a blue print and basic standards for the management of fisheries resources. Its feature laid down common principles for adoption national and regional practices to stop or reduce illegal fishing. The International Labour Organization (ILO) by a report in 2013 stated that the West Coast of Africa is indeed open to illegal fishing with a massive third of the total catch falling in the category of illegal fishing [31]. Estimates from the World Bank and claims from the European Union (EU) suggests that an amount of $\$ 350$ million is lost by the economies of the coastal West African states [32]. There has been a keen resolve by the coastal West African countries to create an effective monitoring system to control the activities of IUU fishing. This has culminated in the formation of regional initiatives to enhance greater cooperation, with the partnership for Africa (PFA) being one such example.

Figure 3 shows the distribution of owners whose vessels engage in IUU and are under the flag of convenience (FOC) and others that fall in between.

\section{Present Countermeasures}

To create an effective counter measures for incidents of piracy in the Gulf of Guinea (GoG) has to thoroughly understand the kind of business model used by pirates in different geographical areas. In the Gulf of Guinea, the pirates keep modifying their modus operandi. In the Nigerian waters, fishing vessels fall prey to pirates who use them as "mother ships" or launch pads for their attacks. These pirates are often heavily armed with AK-47's assault rifles and other sophisticated arms. Fast skiff undertake the actual attack. With the help of the mother ships, pirates are able to travel further out to sea and concentrate on vessels laden with oil. These are deep draught vessels that often sail in deeper waters. 


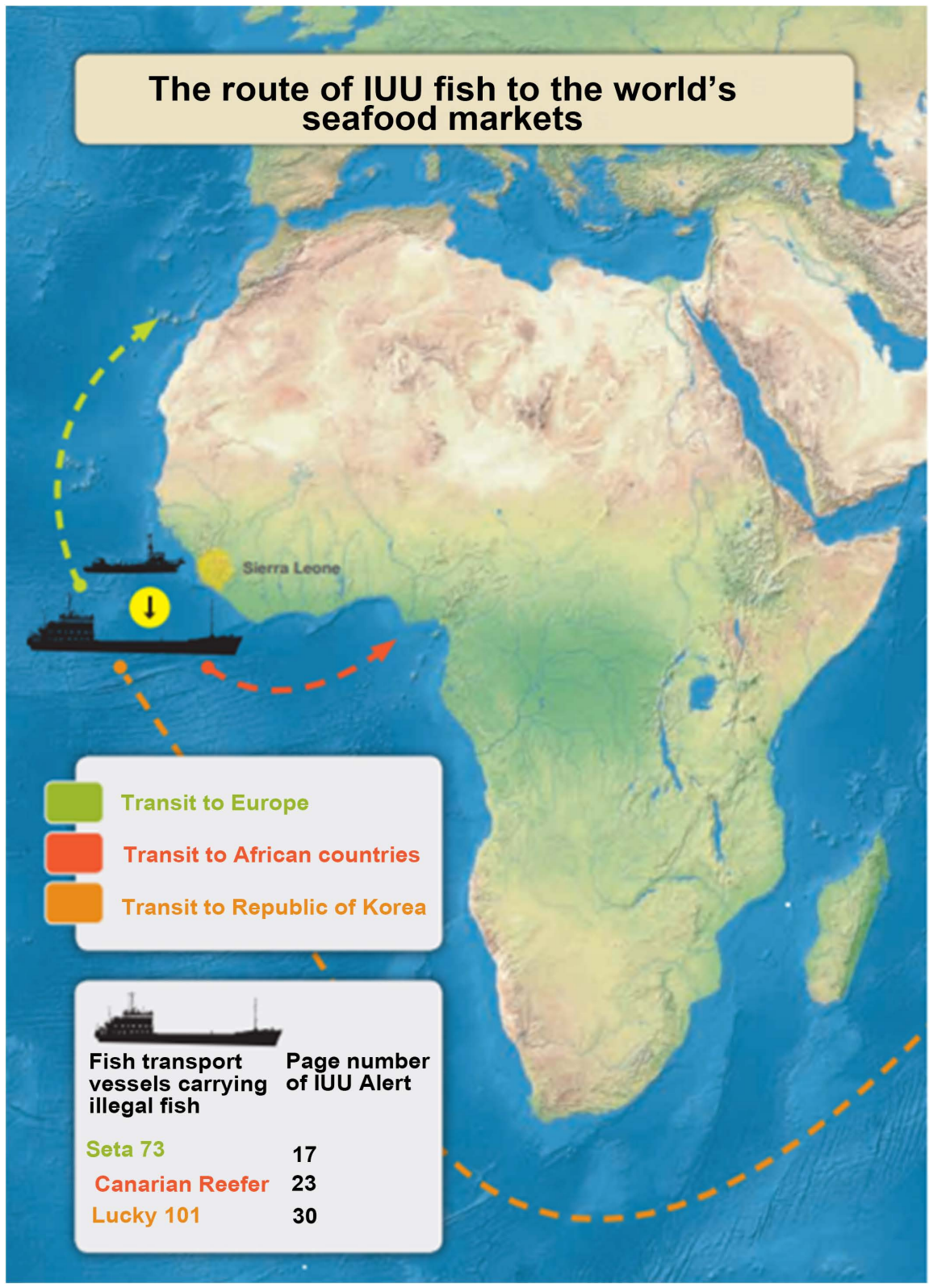

Figure 3. Source: (Environmental Justice Foundation, 2012)

https://ejfoundation.org//resources/downloads/Pirate-Fishing-Exposed.pdf.

According to [33] piracy in the GoG is very sophisticated and well executed to capture oil cargoes. The stolen oil is white washed through black market circles and then released back into the global supply chain. Unlike the Gulf of Aden where there are specially demarcated Sea Lines of Communication (SLOC), which is protected by an international force creating a safe corridor for ship transit, there is no such equivalent in the Gulf of Guinea. The United States with a seed money of $\$ 3$ million annually created the African Costal Security program in 1985. It fizzled out by the year 1995 due to insufficient funding. To create further awareness of the of the maritime security needs of the Gulf of Guinea, the United States Navy affirmed and referred to the Maritime Domain Awareness 
(MDA). This emphasized that a nation's territorial waters and Exclusive Economic Zone (EEZ) should be well guarded using surveillance devices like Radar and other tools such as the Automatic Identification System (AIS) and the Long Range Identification and Tracking (LRIT) system [34].

\section{Conclusion}

It is a daunting task to come up with a specific causative factor for the insecurity in the Gulf of Guinea. There are certain underlying currents which tend to shape and define the region. African countries depend heavily on seaborne trade as a primary means to get their goods into the supply chain. This vector for movement of merchandise translates into about 90 percent of global trade. This "blue economy" is heavily threatened by the surge of maritime piracy. Countries in the Gulf of Guinea now have new maritime security challenges to deal with. For the collective security of the Gulf of Guinea states, Maritime Security plays a pivotal role and a key element. However, a substantial number of East and West African countries lack the political will, resources and a functioning system in governance. This handicap has crystallized into preventing their territorial waters and their Exclusive Economic Zone (EEZ) in effective monitoring and protection of these zones. Piracy in the Gulf of Guinea has one unique footprint as it is associated with the production of crude oil and the theft and hijacking of this commodity. Oil tankers are the most vulnerable of ships due to their construction and valuable cargo they carry. It is easy to make a ship-to-ship transfer of seized oil cargoes and with a ready black market and private networks the cargo is easily siphoned off for sale. It is prudent that ship owners and operators engage known reputable manning agencies to hire people who are highly skilled and can put in place evasive maneuvers and contingencies to avert any surprise pirate attacks. Maritime insecurity is multi-headed and very complicated to deal with. Depending on where the acts of violence was committed gives definition to the act. The outcomes are often similar because the acts are mostly interlinked. The problem of insecurity has been worsened by West African notoriously becoming a narcotics transit point for drug Lords in South America. The shipmaster is responsible for the overall safety of the crew and ship. Through traffic simulation the sailing vessels along the Gulf of Guinea (GoG) corridor, different scenarios of collision could be generated using the given models on collision. Ship owners in making decisions on where to operate their vessels and the use of risk and cost-benefit assessments could use the novel Formal Safety Assessment methodology (FSA).

\section{References}

[1] ICS (2013) Annual Report 2013

http://www.ics-shipping.org/shipping-facts/shipping-and-world-trade

[2] ICS (2017) ICS Annual Review 2017. http://www.ics-shipping.org/shipping-facts/shipping-and-world-trade 
[3] Giddenes, A. (1994) Beyond Left and Right. Stanford University Press, Stanford, CA.

[4] Ma, S. (1999) Maritime Economics. Unpublished Lecture Handout, World Maritime University Malmö Sweden.

[5] Saul, J. (2009) Pirates Pose Deadly Threat in Gulf of Guinea, Reuters Online. http://www.reuters.com/article'/idUSGEEB113D

[6] West Africa Waters Receive High Piracy Risk Designation (2012). http://gcaptain.com/west-africa-waters-receive-high/

[7] IMO (2011) International Convention on Standards of Training, Certification and Watch Keeping for Seafarers (1995) including 2010 Manila Amendments. IMO, London.

[8] United Nations Office on Drugs and Crime (2013) Transnational Organized Crime in West Africa: A Threat Assessment. UNDOC, Vienna.

[9] Bridger, J. (2014) Kidnapping Resurgent in Gulf of Guinea Piracy. USNI News, March 2014

https://news.usni.org/2014/03/14/kidnapping-resurgent-gulf-guinea-piracy

[10] IMB (2016) Piracy and Armed Robbery against Ships, Report for the Period $1^{\text {st }}$ January to September 2016.

[11] Bernstein, P.L. (1998) Stock Market Risk in a Post Keynesian World. Journal of Post Keynesian Economics, 21, 15-24. https://doi.org/10.1080/01603477.1998.11490176

[12] March, J.G. and Shapira, Z. (1987) Managerial Perspectives on Risk and Risk Taking. Management Science, 33, 1404-1418. https://doi.org/10.1287/mnsc.33.11.1404

[13] Greenberg, M., Chalk, P., Willis, H., Khilko, I. and Ortiz, D. (2006) Maritime Terrorism: Risk and Liability. RAND Corporation Centre for Terrorism and Risk Management Policy, Santa Monica, CA.

[14] IMO (2002) Guidelines for Formal Safety Assessment (FSA) for Use in the IMO Maritime Safety Committee by Denmark at the $69^{\text {th }}$ Session, 1998.

[15] Allen, R.E. (1990) The Oxford Concise Dictionary. The Claren Press, Oxford.

[16] Ayyub, B.M., Beach, J.E., Sarkani, S. and Assakkaf, I.A. (2002) Risk Analysis and Management for Marine System. NEJ, ASNE, 114, 181-206.

[17] Friis-Hansen, P. and Pedersen, P.T. (1998) Risk Analysis of Conventional and Solo Watch Keeping. Submitted to International Maritime Organization (IMO) Maritime Safety Committee by Denmark at the 69th Session.

[18] Merrick, J.R.W. and van Dorp, J.R. (2006) Speaking the Truth in Maritime Risk Assessment. Risk Analysis, 26, 223-237. https://doi.org/10.1111/j.1539-6924.2006.00708.x

[19] Macduff, T. (1974) Probability of Vessel Collisions. Ocean Industry, 9, 144-148.

[20] Kristiansen, S. (2005) Traffic-Based Models. In: Maritime Transportation-Safety Management and Risk Analysis, 133-171.

[21] Rodger, C. and Petch, J. (1999) Uncertainty \& Risk Analysis-A Practical Guide from Business Dynamics. Business Dynamics, Price Waterhouse Coopers United Kingdom Firm.

http://clem.mscd.edu/ mayest/Excel/Files/Uncertainty\%20and\%20Risk\%20Analysi s.pdf

[22] Palisade (2005) Guide to Using RISK-Advanced Risk Analysis for Spreadsheets. Palisade Corporation. 
[23] Cormier, P.J. (1994) Towing Vessel Safety: Analysis of Congressional and Coast Guard Investigative Response to Operation Involvement in Casualties Where a Presumption of Negligence Exists. Master's Thesis, University of Rhode Island.

[24] Bryant, D.T. (1991) The Human Element in Shipping Casualties. Report Prepared for the Dept. of Transportation, Marine Directorate.

[25] UK DPT (1987) MV Herald of Free Enterprise-Fatal Accident of Formal Safety Assessment to the IMO Rule-Making Process. Sheen Report, Report of Count No. 8074, UK Department of Transport, HMSO.

[26] Wang, J. (2002) Offshore Safety Case Approach and Formal Safety Assessment of Ships. Journal of Safety Research, 33, 81-115. https://doi.org/10.1016/S0022-4375(02)00005-1

[27] Wang, J. and Trbojevic, V.M. (2007) Design for Safety of Large Marine and Offshore Engineering Products. Institute of Marine Engineering, Science and Technology, London.

[28] Hawkes, K.G. (1989) Maritime Security. 9.

[29] Howard, J. (2013) Obangame Express 2013 Comes to a Close, March 1, 2013. http://www.africom.mil/Newsroom/Article/10389/excercise-express

[30] EJF (2012) Pirate Fishing Exposed: The Fight Against Illegal Fishing in West and the EU.

[31] International Labour Organization (2013) Caught at Sea: Forced Labour and Trafficking in Fisheries. ILO, Geneva.

[32] European Union (2014) Fact Sheet: EU Strategy on the Gulf of Guinea. EU, Brussels.

[33] Malaquais, A. (2010) Ask the Expert: The Growing Threat of Oil Pirates in West Africa's Gulf of Guinea. ACSS News Spotlight.

[34] JFQ (2007) Joint Forum Quarterly-Maritime Security in the Gulf of Guinea Issue 45. 2nd Quarterly 2007. 